\section{The Imperial College of Tropical Agriculture.}

A

$\mathrm{T}$ a luncheon at the Mansion House on January 29, given by the Lord Mayor of London and the governing body of the Imperial College of Tropical Agriculture, which is now getting into the swing of its work in Trinidad, Lord Milner's recent appeal for more funds for the endowment of the College was supported by a number of speeches which are of good augury for the future of scientific work in the British tropical colonies.

The Secretary of State for the Colonies (Mr. Amery), in proposing the toast of the College, said that it is an enterprise that holds out great hope in regard to the development of that great imperial asset, the tropical colonies. It is in this light that one should regard itnot as a local affair in Trinidad, but as an Imperial institution, the work of which will have a most important bearing upon the progress of our great tropical Empire. This has been much neglected in the past, though it has contributed so much to the wealth of the mother country-through sugar in the West Indies, coffee, coconuts, and tea in India and Ceylon, rubber in Malaya and Ceylon, jute, rice, and many other commodities in India.

From the wetter parts of our tropical possessions we obtain most of our supplies of cacao, cinchona bark for quinine, coconuts and their oil (for soap), copra, coir fibre, coffee, guttapercha, jute (for gunny bags), palm oil (for soap and lubricants), palm fibre (for brushes), rice, rubber, sago, spices, sugar, tea, tapioca, and many fruits, including the banana, and from the drier parts we obtain much tobacco and other products. Tropical Africa now bids fair to go far towards supplying Great Britain with cotton.

Such being the case, one might expect to find much money spent upon the development of the tropical colonies and everything connected with them (especially matters concerned with agriculture and its teaching). In actual fact, their development has largely been effected out of their own revenues, which are in general modest, as they depend mainly upon agriculture. An important departure from this method has recently been made, and the home Government has advanced a large loan to some of the tropical African colonies, with the express object of enabling a rapid development of their systems of transport.

With the great competitive extension of planting and of agriculture generally that is now going on in the tropics, the lack of appreciation of the importance of such an institution as the Imperial College must be due to want of thought. Surely this only needs to be pointed out for some of our wealthy firms and indi- viduals, who have won prosperity from the great industries of rubber, tea, coffee, cotton, coconuts, and other products of the tropics, to come forward with important contributions towards the $100,000 \mathrm{l}$. for which Lord Milner has appealed - an endowment to enable the College to make proper use of its great opportunities.

Let it be always remembered that the College is the Imperial College of Tropical Agriculture, and that it is to train men not for Trinidad alone, but for all the widely flung tropical dependencies of the British Empire. It has already received some munificent endowments, but is in need of many more. Its land and its largest cash endowment it owes to the Government of Trinidad. It has received machinery to the value of $20,000 l$. from the British Sugar Machinery Manufacturers, and has erected a model sugar factory. Messrs. Davidson and Todd, of Port of Spain, have presented the furniture, made of local woods, for the main hall of the College. Equipments for rubber, tea, cotton, and others are equally to be desired, and expert staffs are needed to manage them.

That important organisations are placing faith in the future value of the College is seen from the fact that the Empire Cotton Growing Corporation, with an executive council composed mainly of Lancashire business men, is sending many of its students to be trained there. These men will have in their hands the chief part in the development of this great industry within the British Empire.

One of the greatest desiderata in the proper opening up of our tropical possessions is a due care for health, and in this connexion it was of great interest to learn from the speech of Sir Arthur Shipley (chairman of the governors) that "the Trustees of the International Health Board (who control the Rockefeller endowments), after careful inquiry into the efficiency and standing of the College, have offered roool. a year for five years to establish a professorship of tropical sanitation and hygiene"; and if this proves a success, Sir Arthur has no doubt that they will continue their benefaction. This still further emphasises the need of the institution for further endowment and equipment.

With the opening of the Imperial College, the older methods of rule of thumb will tend to disappear in the light of modern scientific study, as they have all but disappeared in medicine or surgery. The chance for the young men of to-day, as against their predecessors of thirty years ago, is brighter to an almost incredible degree, provided that men of as good and as capable a type are ready to take advantage of it. Let us wish all prosperity to the Imperial College of Tropical Agriculture under the capable guidance of Dr. Hugh Martin Leake, its new principal, who has lately succeeded to the great pioneer of its fortunes, Sir Francis Watts.

NO. 2884 , vOL. I I 5$]$ 